Research Article

\title{
Cytogenetic variation of repetitive DNA elements in Hoplias malabaricus (Characiformes - Erythrinidae) from white, black and clear water rivers of the Amazon basin
}

\author{
Fabíola Araújo dos Santos $^{1,2}$, Diego Ferreira Marques ${ }^{1,2}$, Maria Leandra Terencio ${ }^{3}$, Eliana Feldberg ${ }^{3}$ \\ and Luís Reginaldo R. Rodrigues ${ }^{1,2}$ \\ ${ }^{1}$ Laboratório de Genética \& Biodiversidade, Instituto de Ciências da Educação, Universidade Federal do \\ Oeste do Pará, Santarém, PA, Brazil \\ ${ }^{2}$ PPG Recursos Naturais da Amazônia, Universidade Federal do Oeste do Pará, Santarém, PA, Brazil \\ ${ }^{3}$ Laboratório de Citogenética Animal, Instituto de Pesquisas da Amazônia, Manaus, AM, Brazil
}

\begin{abstract}
Hoplias malabaricus is a common fish species occurring in white, black and clear water rivers of the Amazon basin. Its large distribution across distinct aquatic environments can pose stressful conditions for dispersal and creates possibilities for the emergence of local adaptive profiles. We investigated the chromosomal localization of repetitive DNA markers (constitutive heterochromatin, rDNA and the transposable element REX-3) in populations from the Amazonas river (white water), the Negro river (black water) and the Tapajós river (clear water), in order to address the variation/association of cytogenomic features and environmental conditions. We found a conserved karyotypic macrostructure with a diploid number of 40 chromosomes (20 metacentrics +20 submetacentrics) in all the samples. Heteromorphism in pair 14 was detected as evidence for the initial differentiation of an XX/XY system. Minor differences detected in the amount of repetitive DNA markers are interpreted as possible signatures of local adaptations to distinct aquatic environments.
\end{abstract}

Keywords: cytogenomics, FISH, rDNA, REX 3, Tapajós river.

Received: April 13, 2015; Accepted: August 02, 2015.

\section{Introduction}

The rivers in the Amazon basin, South America, are usually categorized based on the appearance of their water color type. Traditionally, these rivers are recognized as white, clear and black water types (Goulding, 1997). This classification system has been formally considered since the 1950s and is supported based on differences in water chemical properties, with white water rivers (e.g. Amazonas) having a neutral $\mathrm{pH}$ and turbid water, clear water rivers (e.g. Tapajós) a $\mathrm{pH}$ variable between 5 to 8 and a greenish water color, and black water rivers (e.g. Negro) having an acidic $\mathrm{pH}$ of $<5$ and a brownish water color (Sioli, 1984).

An enormous diversity of fishes and other aquatic organisms inhabits the Amazon basin, where they interact with equally diverse, heterogeneous and dynamic habitats (Val and Almeida-Val, 1995). Genetic divergence is also expected from populations occurring in such distinct envi-

Send correspondence to Luís Reginaldo R. Rodrigues. Laboratório de Genética \& Biodiversidade, UFOPA - Campus Tapajós, Rua Vera Paz, SN, 68035-110, Salé - Santarém, PA, Brazil. E-mail: luisreginaldo.ufpa@ hotmail.com ronment conditions. Farias and Hrbek (2008), observed restriction of gene flow between 'brown' discus and 'Heckel' discus (Symphysodon) populations from the Amazonas and Negro rivers, which was interpreted as result of local adaptation to distinct environments.

The understanding of how fish genomes interact to provide local adaptations to specific environmental conditions and their fluctuation is a frontier of scientific knowledge. Repetitive DNA represents a large portion of fish genomes and may play a role in genome structure maintenance, chromosomal physiology and possibly local adaptations processes (Charlesworth et al., 1994; Burt and Trivers, 2006). Such genomic elements are observed as tandem arrays (minisatellite and microsatellite sequences) or dispersed repeats (transposons and retrotransposons) (Martins, 2007).

It is noteworthy that transposable elements mobility can be induced by environmental factors that contribute as source of new genetic variability that can be useful in the face of stressful conditions (Capy et al., 2000). Gross et al. (2009), have detected variation in the genomic organization of retroelement Rex 3 in Symphysodon spp. from distinct Amazon rivers. Such variation has been tentatively ex- 
plained as local adaptations to water chemistry conditions. Dramatic transcriptomic response and genome sequence variation have been demonstrated in the Killifish (Fundulus heteroclitus) subjected to acclimation to extreme osmotic shock and pollution tolerance (Whitehead et al., 2011).

Fish genomes are rich in all kinds of transposable elements (TEs) (Volff et al., 2000). Physical mapping of TEs in different orders of fishes revealed a clustered pattern in Tetraodontiformes, but was variable in Perciformes, with several species exhibiting a dispersed pattern mode (Martins, 2007). The non LTR-retrotransposons Rex 1 and Rex 3 are abundant in teleost genomes, and have a predisposition to play a role in genome evolution and karyotype reorganization (Volff et al., 1999; 2000; Ozouf-Costaz et al., 2004; Gross et al., 2009). A clustered distribution of Rex3 has been found in Astronotus ocellatus (Mazzuchelli and Martins, 2009) and Symphysodon spp. (Gross et al., 2009), both groups being native from the Amazon basin (Nelson, 2006). Interestingly, in the former, Rex3 is co-localized with centromeric heterochromatin of all the chromosomes, while in the latter the accumulation of Rex 3 is preferentially in a few pairs. If the variation in the amount and/or distribution of TE in the genome of Amazonian fishes has a correlation with local adaptation is not clear.

In order to contribute to the knowledge of genome structure of Amazonian fishes we mapped the chromosomal localization of repetitive DNA elements in the karyotype of Hoplias malabaricus (Characiformes Erythrinidae). This species is widespread throughout the Amazonian basin, occurring naturally in white, black and clear water environments. H. malabaricus is believed to harbor a species complex with seven distinct cytotypes, designated by letters A-G, and distinguished by clear chromosomal features, such as diploid number, presence/absence of sexual chromosome system and chromosome morphology (Bertollo et al., 2000).

\section{Materials and Methods}

\section{Sampling and chromosome preparation}

We collected 60 specimens of Hoplias malabaricus from the Amazonas river (white water environment; $\mathrm{n}=$ 20), Tapajós river (clear water environment; $n=20$ ) and Negro river (black water environment; $\mathrm{n}=20$ ) (for details see Table 1). Taxonomic identification was provided by examination of external characters following Oyakawa and Mattox (2009). Vouchers were fixed in formalin 10\%, preserved in ethanol 70\% and stored in the Fish Collections of Instituto Nacional de Pesquisas da Amazônia (INPA) and Universidade Federal do Oeste do Pará (UFOPA).

Metaphasic chromosomes were obtained from kidney cells extracted in the field after treatment with colchicine $0.0025 \%$ in a dosage of $1 \mathrm{~mL}$ per $100 \mathrm{~g}$ of body mass (Bertollo et al., 1978). The fishes were anesthetized with crave oil mixed with aquarium water before the tissue sampling.

\section{Karyotype and banding procedures}

To determine diploid number we counted at least 30 metaphases that were conventionally stained with Giemsa diluted in phosphate buffer at $2 \%$. At least five spreads were digitally photographed and the karyotypes organized using Adobe Photoshop version7. For chromosome nomenclature we followed Levan et al. (1964). Heterochromatic regions were detected with C-banding (Sumner, 1972). The Nucleolar Organizing Regions (NORs) were revealed by impregnation with silver nitrate following a standard protocol provided in Howell and Black (1980). Metaphases were stained with chromomycin A3 (CMA3) in order to detect $\mathrm{GC}$ rich bands, following the procedure of Schweizer (1980).

Table 1 - Sampling localities of Hoplias malabaricus from Amazon basin.

\begin{tabular}{|c|c|c|c|c|}
\hline River & Aquatic Environment & Exact sites & GPS & Field number of vouchers* \\
\hline Amazonas & White water & $\begin{array}{l}\text { Comunidade Camaleão, Al- } \\
\text { meirim-PA; } \\
\text { Rio Amazonas, Santarém-PA }\end{array}$ & $\begin{array}{l}\mathrm{S} 1^{\circ} 31^{\prime} 13.2^{\prime \prime} / \\
\mathrm{W} 52^{\circ} 33^{\prime} 34.1^{\prime \prime} \\
\mathrm{S} 2^{\circ} 24^{\prime} 8.8^{\prime \prime} / \\
\text { W } 54^{\circ} 42^{\prime} 51.2^{\prime \prime}\end{array}$ & $\begin{array}{l}\text { AMA-1(m), AMA-2(m), AMA-4(f), AMA-5(m), AMA } \\
\text {-6(f), AMA-7(f), AMA-13(f), AMA-14(m), AMA-15(m) } \\
\text {, AMA-16(m), AMA-17(f), AMA-18(m), ALM-2(m), A } \\
\text { LM-5(f), ALM-6(m), ALM-8(m), ALM-9(f), ALM-10(f } \\
\text { ), ALM-11(f), ALM-12(f) }\end{array}$ \\
\hline Tapajós & Clear water & $\begin{array}{l}\text { Lago Bem bom, Miritituba- } \\
\text { PA; } \\
\text { Lago Juá, Santarém-PA }\end{array}$ & $\begin{array}{l}\mathrm{S} 4^{\circ} 18^{\prime} 28.8^{\prime \prime} / \mathrm{W} \\
55^{\circ} 59^{\prime} 0.9^{\prime \prime} \mathrm{S} \\
2^{\circ} 26^{\prime} 40.0 " \prime / \mathrm{W} 54^{\circ} \\
47^{\prime} 21.1^{\prime \prime}\end{array}$ & $\begin{array}{l}\text { JUA-9(m), JUA-13(f), JUA-14(m), JUA-15(m), ITA- } \\
\text { 47(m), ITA-48(f), ITA-66(f), ITA-70(m), ITA-71(m), IT } \\
\text { A-102(m), ITA-104(f), ITA-105(m), ITA-107(m), ITA-1 } \\
\text { 09(m), ITA-110(m), ITA-112(f), ITA-113(m), ITA- } \\
\text { 114(m), ITA-116(m), ITA-117(m) }\end{array}$ \\
\hline Negro & Black water & Lago Catalão, Manaus-AM & $\begin{array}{l}\text { S 309' } 47^{\prime \prime} \text { / } \\
\text { W } 59^{\circ} 54^{\prime} 29^{\prime \prime}\end{array}$ & $\begin{array}{l}\text { 10195(?), 10224(?), 10244(?), 10409(m), 10411(m), } \\
11121(\mathrm{~m}), 11122(\mathrm{~m}), 11123(\mathrm{f}), 11124(\mathrm{~m}), 11125(\mathrm{~m}), 11 \\
126(\mathrm{~m}), 11127(\mathrm{~m}), 11128(\mathrm{f}), 11129(\mathrm{~m}), 11130(\mathrm{~m}), 113 \\
1(\mathrm{~m}), 11132(\mathrm{f}), 11133(\mathrm{~m}), 11134(\mathrm{~m}), 11135(\mathrm{~m})\end{array}$ \\
\hline
\end{tabular}

*In parentheses, sex of each individual, (m) for male and (f) for female (?) not identified. 
DNA extraction, PCR and fluorescent in situ hybridization (FISH)

Genomic DNA was extracted from heart muscle tissue of Hoplias malabaricus following a standard phenolchloroform protocol (Sambrook and Russell 2001).

Repetitive DNA probes were prepared by PCR using the primers cited in literature as follows: $r D N A 5 S-5 \mathrm{Sa}$ (5-TAC GCC CGA TCT CGT CCG ATC) and 5Sb (5-CAG GCT GGT ATG GCC GTA AGC-3) Komiya and Takemura (1979); $\boldsymbol{R e x 3}$ - RTX3-F3 (5-CGG TGA YAA AGG GCA GCC CTG-3) and RTX3-R3 (5-TGG CAG ACN GGG GTG GTG GT-3), Volff et al. (1999; 2001).

The reactions were carried out in a final volume of $15 \mu \mathrm{l}$ consisting of: $1 \mu \mathrm{l}$ of genomic DNA of Hoplias malabaricus ( $200 \mathrm{ng} / \mu \mathrm{l}) ; 1.5 \mu \mathrm{l}$ buffer 10X; $2.4 \mu \mathrm{l}$ of dNTP $\operatorname{mix}(1.25 \mathrm{mM}) ; 0.6 \mu \mathrm{l} \mathrm{MgCl} 2(50 \mathrm{mM}) ; 0.6 \mu \mathrm{l}$ of each primer $(5 \mathrm{mM}) ; 0.12 \mu \mathrm{l}$ Taq DNA polymerase $(5 \mathrm{U} / \mu \mathrm{l})$ and $8.18 \mu \mathrm{l}$ of ultrapure water. The PCR profiles for rDNA5S was: $94^{\circ} \mathrm{C}$ for $1 \mathrm{~min}$, followed by 30 cycles of $94^{\circ} \mathrm{C}$ for 1 min, $57^{\circ} \mathrm{C}$ for $1 \mathrm{~min}, 72^{\circ} \mathrm{C}$ for $90 \mathrm{~s}$, an a final extension at $72^{\circ} \mathrm{C}$ for $5 \mathrm{~min}$. For $\operatorname{Rex} 3$ it was: $95^{\circ} \mathrm{C}$ for $2 \mathrm{~min}$, followed by 35 cycles of $95^{\circ} \mathrm{C}$ for $1 \mathrm{~min}, 55^{\circ} \mathrm{C}$ for $40 \mathrm{~s}, 72^{\circ} \mathrm{C}$ for 2 min, and a final extension at $72{ }^{\circ} \mathrm{C}$ for $5 \mathrm{~min}$.

Positive reactions were visualized on $1 \%$ agarose gels stained with GelRed (Biotium-Uniscience). PCR products were used in a second reaction for probe labeling with biotin-14-dATP by nick translation with the BioNick Labeling System kit (Invitrogen) following the manufacturer's instructions. Hybridization reactions were carried out following the protocol described by Pinkel et al. (1986) with minor modifications. The slides with mitotic preparations were previously incubated with RNase $(5 \mu$ RNase 10 $\mathrm{mg} / \mathrm{ml}$ in $975 \mu \mathrm{l} 2 \mathrm{X} \mathrm{SSC}$ ). Chromosomal DNA was denatured for $5 \mathrm{~min}$ in $70 \%$ formamide in 2 X SSC [17.53g of sodium chloride $(0,29 \mathrm{M}), 8.82 \mathrm{~g}$ of sodium citrate and distilled water in a final volume of $1,000 \mathrm{~mL}, \mathrm{pH} 7.0]$ at $70{ }^{\circ} \mathrm{C}$. The hybridization solution ( $15 \mu \mathrm{l}$ formamide to a final concentration of $50 \%, 6 \mu \mathrm{l}$ of $50 \%$ dextran sulfate, $6 \mu \mathrm{l}$ of denatured probe, $3 \mu \mathrm{l}$ of $20 \mathrm{X} \mathrm{SSC}$ ) was placed onto the slide and incubated in a humid chamber ( 2 X SSC) at $37{ }^{\circ} \mathrm{C}$ overnight. Post hybridization washes were done with $15 \%$ formamide at $42^{\circ} \mathrm{C}$ for $10 \mathrm{~min}$; three washes in $0.1 \mathrm{X} \mathrm{SSC}$ at $60{ }^{\circ} \mathrm{C}$ for $5 \mathrm{~min}$ and $0.5 \%$ Tween 20 at room temperature for $5 \mathrm{~min}$. For signal detection, slides were immersed in NFDM buffer ( $20 \mathrm{~mL}$ of $20 \mathrm{X} \mathrm{SSC}, \mathrm{pH} 7.0 ; 5 \mathrm{~g}$ of powdered skim milk; $80 \mathrm{~mL}$ of distilled water) for $15 \mathrm{~min}$; followed by two washes in 5\% Tween 20 for $5 \mathrm{~min}$ at room temperature. The hybridized probes were detected using conjugated FITC-Avidin (Sigma) in C buffer ( $0.1 \mathrm{M}$ sodium bicarbonate, $0.15 \mathrm{M}$ sodium chloride; $\mathrm{pH}$ 7.0) for $60 \mathrm{~min}$. Signal amplification was done with anti-avidin-biotin $(1 \mu \mathrm{l}$ of antiavidin-biotin and $19 \mu$ of NFDM buffer) incubated in a humid chamber at $37^{\circ} \mathrm{C}$ for $15 \mathrm{~min}$, followed by washes with $5 \%$ Tween 20 and signal detection as described above. The chromosomes were counterstained with DAPI (1,2-diamidin-phenyl-indol) or alternatively with propidium iodide. Slides were mounted with anti-fading reagent Vectashield (Vector).

\section{Microscopy and Image Processing}

Metaphases processed with classical banding methods were photographed in a Zeiss Axioskop microscope using a Canon A640 digital camera, while those subjected to FISH procedures were photographed in an Olympus BX51 coupled with a DP70 CCD camera (Olympus Inc.). The captured images were adjusted for brightness/contrast and the karyotypes were arranged using the software Adobe Photoshop 7.

\section{Results}

The karyotype of Hoplias malabaricus analyzed herein presented a diploid number of $2 \mathrm{n}=40$ chromosomes, consisting of 20 metacentrics and 20 submetacentrics without evidence of differentiated sexual chromosomes under conventional staining (Figure 1).

Heterochromatic bands were visualized at the centromere region of all the chromosomes and the telomere region of a few pairs (Figure 2). The heterochromatic material around the telomeric region seemed to be slightly increased in the samples collected from black water (Figure 2c) than in those from white and clear water environments (Figure 2a, b). Minor size variation could be observed in the centromeric heterochromatin of pair 14, which is consistent with male karyotypes (Figure $2 \mathrm{~b}, \mathrm{c}, \mathrm{d}$ ). This heteromorphism seems to be associated with unequal accumulation of GC content between homologues of pair 14, as demonstrated by CMA3 staining (Figure $2 \mathrm{~d}$ ).

Multiple NORs were visualized on distal portions of chromosomes 6, 8 and 19 (Figure 3), however, slight variation could be evidenced when samples from the distinct environments were compared. In this way, karyotypes representative of white water and black water either showed NORs on the chromosomes 6,8 and 19, but a bitelomeric NOR on chromosome 6 , which was an exclu-

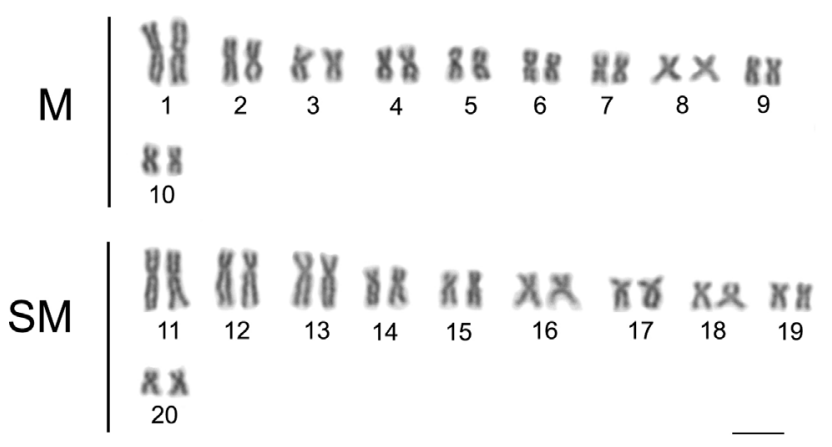

Figure 1 - Conventionally stained karyotype of Hoplias malabaricus ( $2 \mathrm{n}$ $=40$ ) from the Amazon basin. $\mathrm{M}=$ metacentric; $\mathrm{SM}=$ submetacentric; Bar $=5 \mu \mathrm{m}$. Specimen ALM-5 (female). 


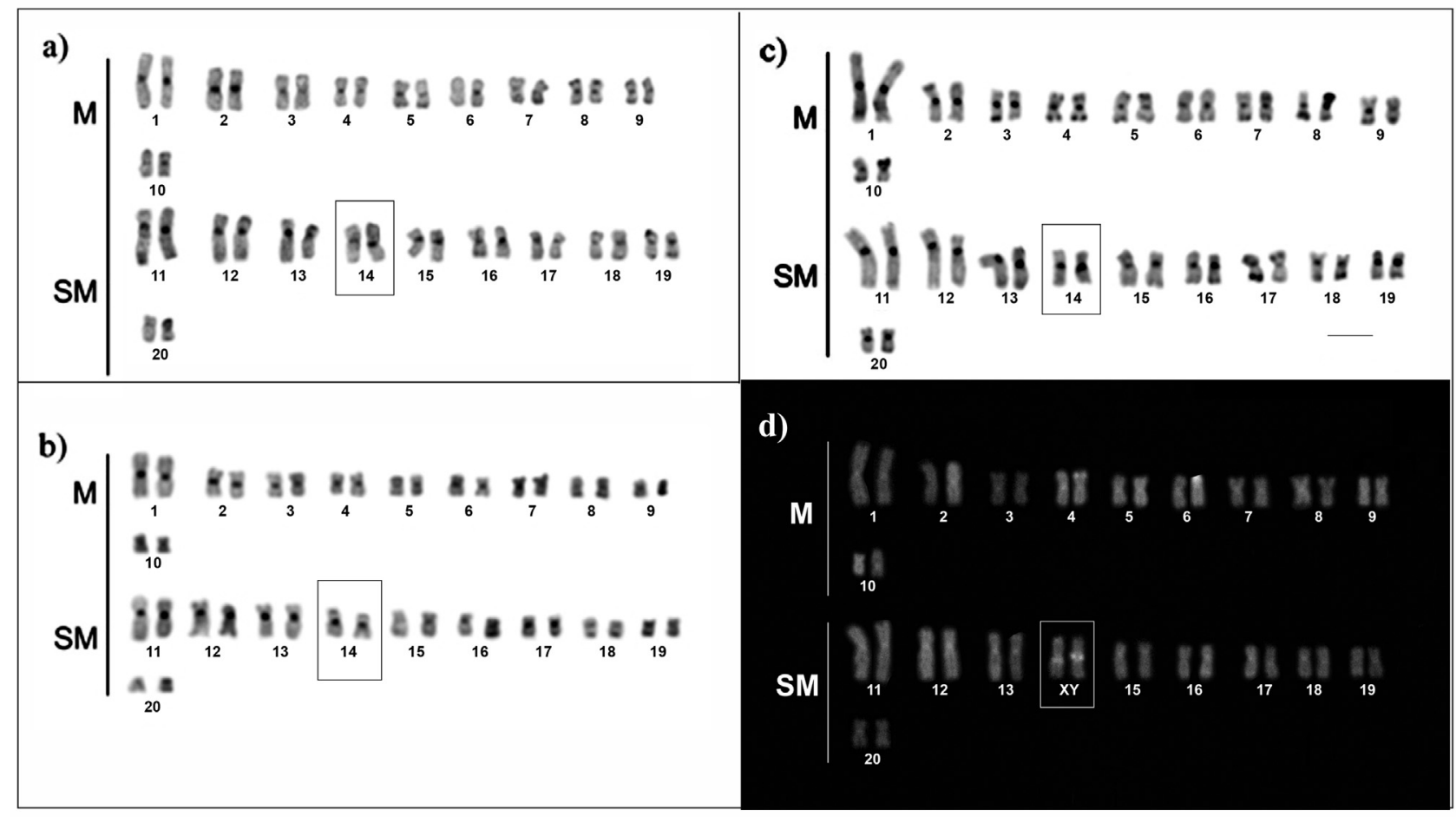

Figure 2 - C-banded (a, b, c) and $\mathrm{CMA}_{3}$ (d) stained karyotypes of Hoplias malabaricus from Amazon basin. The karyotypes are representative of white water (a, d), clear water (b) and black water environments (c). Heteromorphic bands in pair 14 of male karyotypes evidences the nascent XX/XY sexual system. $\mathrm{M}=$ metacentric; $\mathrm{SM}=$ submetacentric; $\mathrm{Bar}=5 \mu \mathrm{m}$. Specimens: a) ALM-5 (female); b) ITA-107 (male); c) 11122 (male), d) AMA-14 (male).

sive trait of samples from black water (Figure 3c). In contrast to the observed in specimens from white and black water environments, samples from clear water river did not show NORs on chromosome 6 (Figure 3b).

$r D N A-5 S$ probes yielded conspicuous fluorescent signals on the chromosomes 14 and 15 (Figure 4). Variation in spot size of the hybridization signal was clearly observed between the homologs of the pair 15 in samples from white water and the pair 14 in those from clear water (Figure 4a, b). Probes of the retroelement Rex 3 showed marked differences between karyotypes of fishes from white water compared to ones from clear and black water. The first exhibited stronger fluorescent signals associated with regions of centromeric heterochromatin, while the latter showed faint signals in a few chromosomes (Figure 5).

\section{Discussion}

It has been well demonstrated that geology, water physical-chemical properties and biological features are responsible for the large heterogeneity of aquatic environments from the Amazon basin (Val and Almeida-Val, 1995; Goulding et al., 2003). This environmental variability plays a role in the local adaptive processes of aquatic life, including an array of morphological, physiological and probably genetic adaptations (Junk et al., 1989).

Cytogenetic markers proved to be important tools to demonstrate variability among Hoplias malabaricus popu- lations (Bertollo et al., 2000; Santos et al., 2009; Jacobina et al., 2011). Based on the similarities observed in diploid number and the gross chromosomal morphology we recognized the karyotype of $H$. malabaricus $(2 \mathrm{n}=40)$ from the Amazon basin in the present study as a representative of cytotype C, as defined in Bertollo et al. (2000). However, when compared with cytotype $\mathrm{C}$ population, from the Bento Gomes river, Mato Grosso (Cioffi et al., 2009a), we detected variation in the karyotypic formulae and NOR labeling sites. Such geographic variation in the macrostructure of cytotype $\mathrm{C}$ could be resultant of chromosome rearrangements like pericentric inversions leading to transformation of metacentric into submetacentric form or viceversa.

Despite of diverging from the Bento Gomes river population in term of gross chromosomal morphology (karyotypic formulae), the H. malabaricus populations from the Amazon basin (present study) preserve signatures of the initial steps toward a nascent sexual chromosome system XX/XY, as suggested in Cioffi and Bertollo (2010). Based on karyotypic comparisons and analyses of C-bands and CMA3 stained metaphases we assume a homology between the sexual chromosome pair XX/XY (pair 11) previously detected (Cioffi and Bertollo, 2010) and pair 14 (Figure 2), recognized herein, as sexual chromosomes in the cytotype $\mathrm{C}$ from the Amazon basin.

Multiple NORs are a common feature of the Hoplias malabaricus genome (Born and Bertollo, 2006; Vicari et 


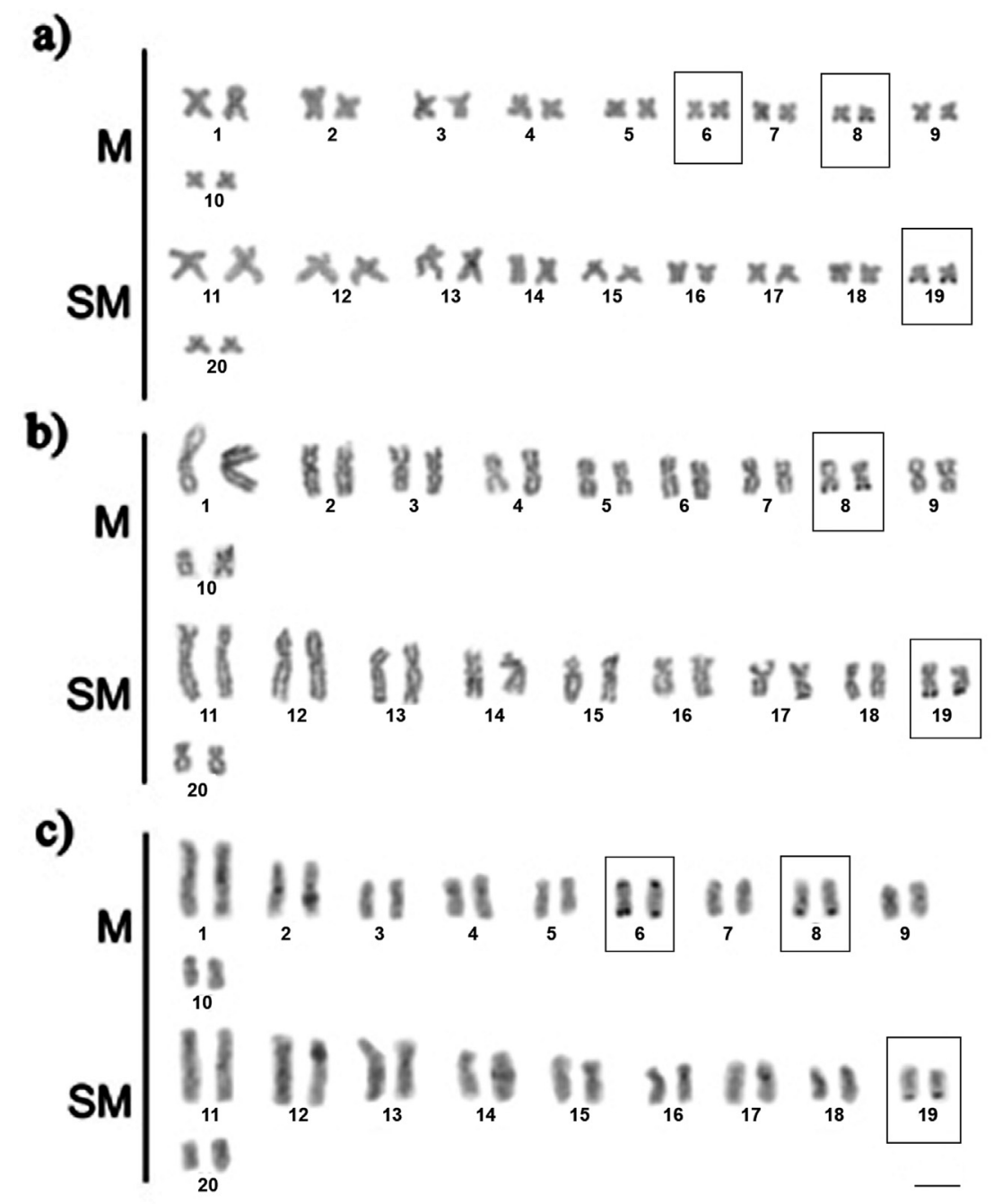

Figure 3 - Silver stained karyotypes of Hoplias malabaricus from the Amazon basin. The NOR bearing chromosomes are in boxes. The karyotypes are representative of white water (a), clear water (b) and black water environments (c). $\mathrm{M}=$ metacentric; $\mathrm{SM}=$ submetacentric; Bar $=5 \mu \mathrm{m}$. Specimen: a) ALM-5 (female); b) JUA-13 (female); c) 11133 (male).

al., 2006; Santos et al., 2009; Cioffi et al., 2009a,b). In the specimens analyzed herein were observed a reduction in the number of NOR bearing chromosomes compared to samples from the Bento Gomes river (Cioffi et al., 2009a). Since the populations of cytotype $\mathrm{C}$ are largely distributed across South America (Bertollo et al., 2000) and their sedentary behavior may favor to reduce gene flow and promote divergence (Blanco et al., 2010), minor variations within the cytotype $\mathrm{C}$ representatives could be expected. Karyotypic differences, including NOR polymorphism, have been recorded in populations of cytotype A, another broadly dispersed cytotype of $H$. malabaricus (Born and Bertollo, 2001; Vicari et al., 2005; Cioffi et al., 2009a; Blanco et al., 2010).

The location of 5S rDNA repeats seems to be conserved among the samples from distinct habitats (white, clear and black waters), but the spot size variation observed in chromosomes 14 and 15 revealed a heteromorphism of this genome region. This phenomenon can be explained by unequal exchange events driving to increase/decrease copy number between homologs (Martins, 2007). Moreover, the accumulation of distinct classes of repetitive DNA may play a role in the differentiation of sexual chromosomes (Cioffi and Bertollo, 2010).

Abundance of Rex 3 retroelement repeats was larger in the samples originating from white water habitat, resembling a compartment fashion of cytogenomic organization. On the other hand, the pattern visualized in karyotypes from clear and black water habitats was interpreted as a dispersed mode. This retroelement has been commonly detected on fish genomes and usually hybridizes in a dispersed mode through all the chromosomes (OzoufCostaz et al., 2004; Ferreira et al., 2010), but sometimes it accumulates on specific chromosomes or chromosomal region, as was observed in $\mathrm{Y}$ chromosome of Chionodraco 

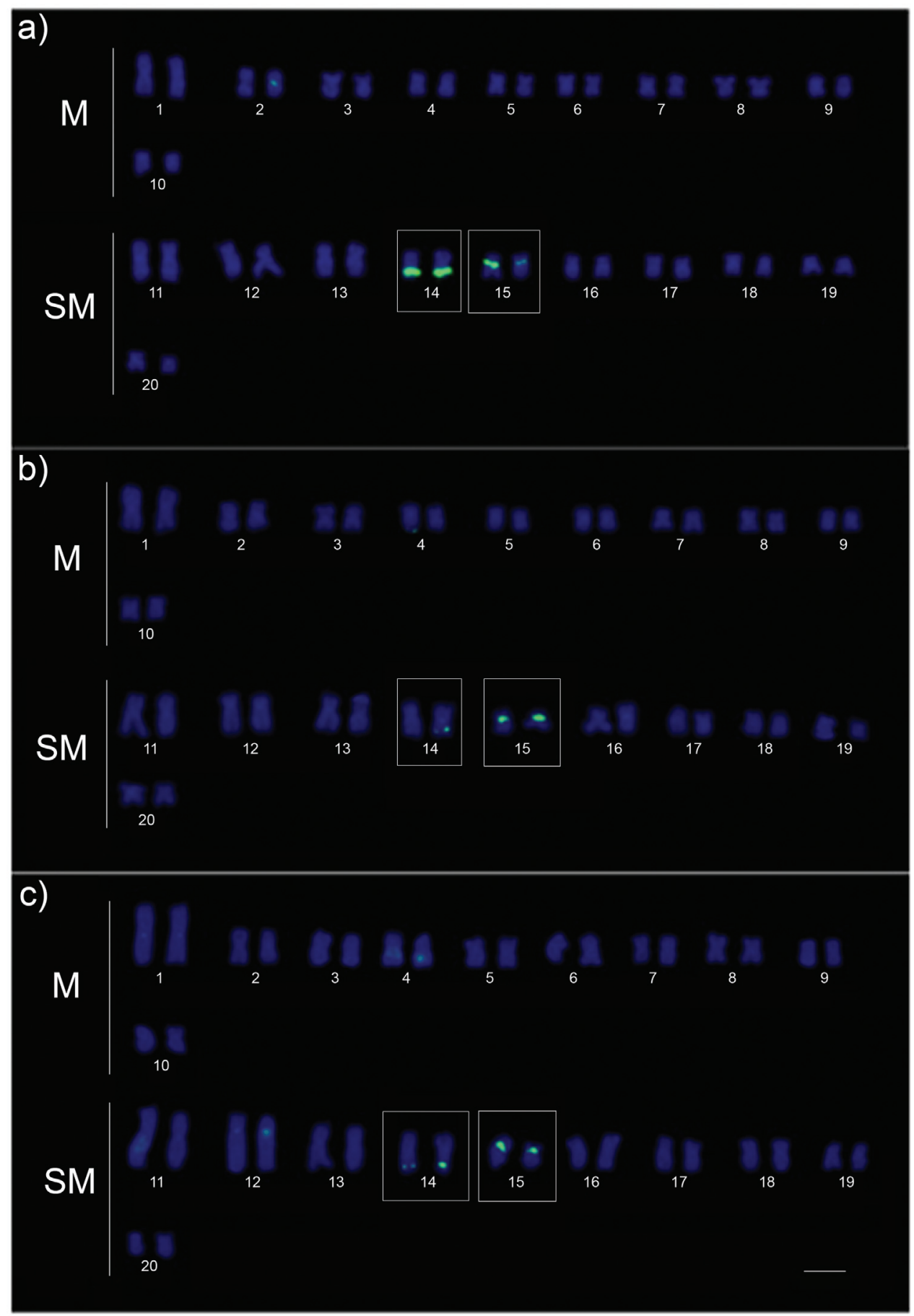

Figure 4 - Localization of rDNA 5S repeats (green) in the karyotypes of Hoplias malabaricus from the Amazon basin, cytotype C. The labeled chromosomes are shown in boxes. The karyotypes are representative of white water (a), clear water (b) and black water environments (c). $\mathrm{M}=\mathrm{metacentric}$; $\mathrm{SM}=$ submetacentric; Bar $=5 \mu \mathrm{m}$. Specimens: a) AMA-14 (male); b) JUA-14 (male); c) 10411 (male).

hamatus (Ozouf-Costaz et al., 2004) and centromeres of Astronotus ocellatus (Mazzuchelli and Martins, 2009).

Transposable elements can respond to changes in cellular and external environment (Capy et al., 2000; Casacuberta and Gonzalez 2013). Vieira and Biémont (1996) evidenced a copy number increase of Drosophila 412 element in response to temperature decrease. Herein we de- tected clear evidence of copy number variation in distinct types of repetitive DNA in the cytogenome of Hoplias malabaricus from white, black and clear water rivers of the Amazonian basin. This result leads to infer a possible mechanism of adaptation by enrichment of Rex3 in Hoplias malabaricus in these different habitats due to stress caused by changes in water properties in the past (Casacuberta and 

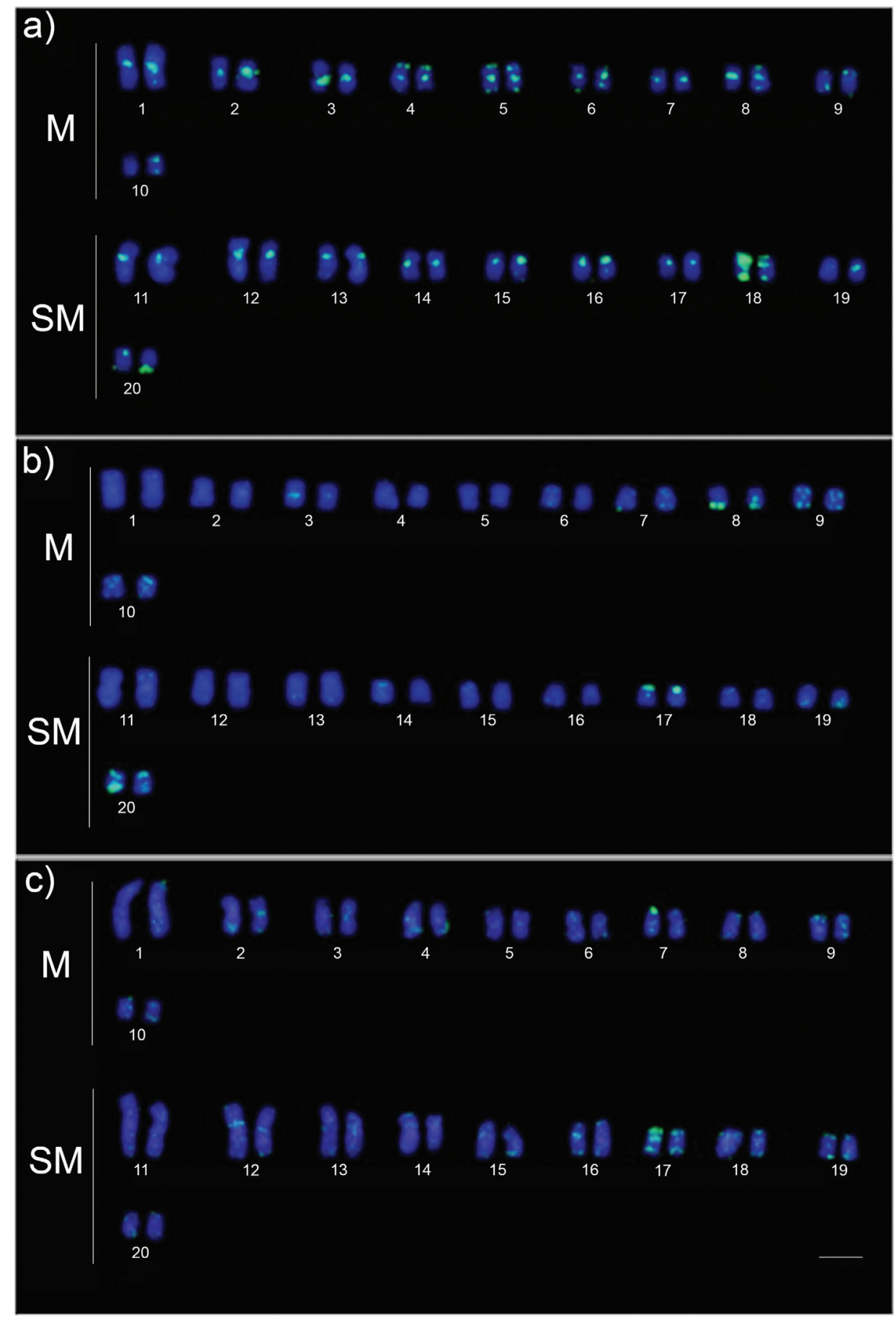

Figure 5 - Hybridization of Rex 3 probes on karyotype of Hoplias malabaricus (cytotype C) from the Amazon basin. The karyotypes are representative of white water (a), clear water (b) and black water environments (c). $M=$ metacentric; $S M=$ submetacentric; Bar $=5 \mu$ m. Specimens: a) AMA-14 (male); b) JUA-14 (male); c) 10411 (male).

Gonzalez, 2013) that maintained this accumulation of retroelement based on the sedentary habits of these fish.

Therefore, we conclude that slight differences observed in Hoplias malabaricus may reflect a fine mechanism of cytogenomic shaping, and possibly represents a signature of ongoing local adaptation processes, since the populations studied herein inhabit markedly distinct aquatic environments. Further studies are needed to explore this hypothesis and shed light on how the architecture of fish genomes responds to environmental changes.

\section{Acknowledgments}

The authors are grateful to FAPEAM (Fundação de Amparo à Pesquisa do Estado do Amazonas) for grants to 
E. Feldberg (PRONEX-Edital 003/2009) and INCTAdapta Amazônia (CNPq) for partial financial support. To FAPESPA (Fundação de Amparo à Pesquisa do Estado do Pará) and CAPES for fellowships conceded to FAS and DFM. This research was authorized by IBAMA/SISBIO (License $\mathrm{N}^{\circ}$ 24384-1).

\section{References}

Bertollo LAC, Born GG, Dergam JA, Fennochio AS and Moreira-Filho O (2000) A biodiversity approach in the neotropical Erythrinidae fish, Hoplias malabaricus. Karyotypic survey, geographic distribution of cytotypes and cytotaxonomic considerations. Chromosome Res 8:603-613.

Bertollo LAC, Takahashi KS and Moreira-Filho O (1978) Cytotaxonomic considerations on Hoplias lacerdae (PiscesErythrinidae). Braz J Genet 1:103-120.

Blanco DR, Lui RL, Bertollo LAC, Diniz D and Moreira-Filho O (2010) Characterization of invasive fish species in a river transposition region: evolutionary chromosome studies in the genus Hoplias (Characiformes, Erythrinidae). Rev Fish Biol Fisheries 20:1-8.

Born GG and Bertollo LAC (2001) Comparative cytogenetics among allopatric populations of the fish, Hoplias malabaricus. Cytotypes with $2 \mathrm{n}=42$ chromosomes. Genetica 110:1-9.

Born GG and Bertollo LAC (2006) A new sympatric region for distinct karyotypic forms of Hoplias malabaricus (Pisces, Erythrinidae). Braz J Biol 66:205-210.

Burt A and Trivers R (2006). Genes in conflict: the biology of selfish genetic elements. Harvard University Press, Cambridge, MA, $602 \mathrm{pp}$.

Capy P, Gasperi G, Biémont C and Bazin C (2000) Stress and transposable elements: co-evolution or useful parasites? Heredity $85: 101-106$.

Casacuberta E and Gonzalez J (2013). The impact of transposable elements in environmental Adaptation. Mol Ecol 22:15031517.

Charlesworth B, Snegowski P and Stephan W (1994) The evolution dynamics of repetitive DNA in eukaryotes. Nature 371:215-220.

Cioffi MB and Bertollo LAC (2010). Initial steps in XY chromosome differentiation in Hoplias malabaricus and the origin of an $\mathrm{X}_{1} \mathrm{X}_{2} \mathrm{Y}$ sex chromosome system in this fish group. Heredity 105:554-561.

Cioffi MB, Martins C and Bertollo LAC (2009a) Comparative chromosome mapping of repetitive sequences. Implications for genomic evolution in the fish, Hoplias malabaricus. BMC Genet 10:e34.

Cioffi MB, Martins C, Centofante L, Jacobina U and Bertollo LAC (2009b) Chromosomal variability among allopatric populations of Erythrinidae fish Hoplias malabaricus: mapping of three classes of repetitive DNAs. Cytogenet Genome Res 125:132-141.

Farias IP and Hrbek T (2008) Patterns of diversification in the discus fishes (Symphysodon spp. Cichlidae) of the Amazon basin. Mol Phylogenet Evol 49:32-43.

Ferreira DC, Oliveira C and Foresti F (2010) Chromosome mapping of retrotransposable elements Rex 1 and $\operatorname{Rex} 3$ in three fish species in the subfamily Hypoptopomatinae (Teleostei,
Siluriformes, Loricariidae). Cytogenet Genome Res 132:64-70.

Goulding M (1997) História natural dos rios amazônicos. Brasília: Sociedade Civil Mamirauá/CNPq/Rainforest Alliance, 208 pp.

Gross MC, Schneider CH, Valente GT, Porto JIR, Martins C and Feldberg E (2009) Comparative cytogenetic analysis of the genus Symphysodon (Discus fishes, Cichlidae): chromosomal characteristics of retrotransposons and minor ribosomal DNA. Cytogenet Genome Res 127:43-53.

Gross MC, Schneider CH, Valente GT, Martins C and Feldberg E (2010) Variability of 18S rDNA locus among Symphysodon fishes: chromosomal rearrangements. J Fish Biol 76:1117-1127.

Howell WM and Black DA (1980) Controlled silver staining of nucleolus organizer regions with a protective colloidal developer: a 1-step method. Experientia 36:1014-1015.

Jacobina UP, Paiva E and Dergam JA (2011) Pleistocene karyotypic divergence in Hoplias malabaricus (Bloch, 1794) (Teleostei: Erythrinidae) populations in southeastern Brazil. Neotrop Ichthyol 9:325-333.

Junk WJ, Bayley PB and Sparks RE (1989) The flood pulse concept in river-floodplain systems. In: Dodge DP (ed). Proceedings of the International Large River Symposium. Can. Spec. Publ. Fish. Aquat. Sci. 106p.

Levan A, Fredga K and Sandberg AA (1964) Nomenclature for centromeric position on chromosomes. Hereditas 52:201220.

Komiya H and Takemura S (1979) Nucleotide sequence of 5S ribosomal RNA from rainbow trout (Salmo gairdnerii) liver. J Biochem 86:1067-1080.

Martins C (2007) Chromosomes and repetitive DNAs: a contribution to the knowledge of fish genome. In: Pisano E, OzoufCostaz C, Foresti F and Kapoor BG (eds) Fish Cytogenetics. CRC Press, USA, Boca Raton, Florida, pp 421-432.

Mazzuchelli J and Martins C (2009) Genomic organization of repetitive DNAs in the cichlid fish Astronotus ocellatus. Genetica 136:461-469.

Nelson JS (2006) Fishes of the world. Fourth Edition, John Wiley \& Sons, Inc., USA, Hoboken, New Jersey, 601 pp.

Oyakawa OT and Mattox GMT (2009) Revision of the Neotropical trahiras of the Hoplias lacerdae species-group (Ostariophysi: Characiformes: Erythrinidae) with descriptions of two new species. Neotrop Ichthyol 7:117-140.

Ozouf-Costaz C, Brant J, Körting C, Pisano E, Bonillo C, Coutanceau JP and Volff JN (2004) Genome dynamics and chromosomal localization of the non-LTR retrotranposon Rex 1 and Rex3 in Antarctic fish. Antarct Sci 16:51-57.

Pinkel D, Straume T and Gray JW (1986) Cytogenetic analysis using quantitative, high-sensitivity, fluorescence hybridization. Proc Natl Acad Sci USA 83:2934-2938.

Santos U, Völcker CM, Belei FA, Cioffi MB, Bertollo LAC, Paiva SR and Dergam JA (2009) Molecular and karyotypic phylogeography in the Neotropical Hoplias malabaricus (Erythrinidae) fish in eastern Brazil. J Fish Biol 75:2326-2343.

Schweizer D (1980) Simultaneous fluorescent staining of R bands and specific heterochromatic regions (DA/DAPI Bands) in human chromosomes. Cytogenet Cell Genet 27:190-193.

Sioli H (1984) The Amazon and its main effluents: Hydrography, morphology of the river courses, and river types. In: Sioli H 
(ed). The Amazon: limnology and landscape ecology of a mighty tropical river and its basin. W. Junk Publications. Netherlands, Dordrecht, pp 127-166.

Sumner AT (1972) A simple technique for demonstrating centromeric heterochromatin. Exp Cell Res 75:304-306.

Val AL and Almeida-Val VMF (1995) Fishes of the Amazon and their environments. Physiological and biochemical features. Springer Verlag, Heidelberg, 224 pp.

Vicari MR, Pazza R, Artoni RF, Margardo VP and Bertollo LAC (2006) Cytogenetics and Biogeography: considerations about the natural origin of Hoplias malabaricus (Characiformes, Erythrinidae) on the Iguaçu River. Braz Arch Biol Technol 49:297-303.

Vicari MR, Artoni RF and Bertollo LAC (2005) Comparative cytogenetics of Hoplias malabaricus (Pisces, Erythrinidae). A population analysis in adjacent hydrographic basins. Genet Mol Biol 28:103-110.
Vieira C and Biémont C (1996) Geographical variation in insertion site number of retrotransposon 412 in Drosophila simulans. J Mol Evol 42:443-451.

Volff JN, Korting C, Sweeney K and Schartl M (1999) The non-LTR retrotransposon Rex3 from the fish Xiphophorus is widespread among teleosts. Mol Biol Evol 16:1427-1438.

Volff JN, Korting C and Schartl M (2000) Multiple lineages of the non-LTR retrotransposon Rex 1 with varying success in invading fish genomes. Mol Biol Evol 17:1673-1684.

Volff JN, Hornung U and S Chartl M (2001) Fish retroposons related to the Penelope element of Drosophila virilis define a new group of retrotransposable elements. Mol Genet Genomics 265:711-720.

Whitehead A, Galvez F, Zhang S, Williams LM and Oleksiak MF (2011) Functional genomics of physiological plasticity and local adaptation in Killifish. J Hered 102:499-511.

Associate Editor: Yatiyo Yonenaga-Yassuda

License information: This is an open-access article distributed under the terms of the Creative Commons Attribution License (type CC-BY), which permits unrestricted use, distribution and reproduction in any medium, provided the original article is properly cited. 